\title{
21. DATA REPORT: CRETACEOUS OSTRACODE ASSEMBLAGES IN THE ISLAND BEACH CORE, NEW JERSEY COASTAL PLAIN ${ }^{1}$
}

\author{
Gregory S. Gohn ${ }^{2}$
}

\section{INTRODUCTION}

The Island Beach core site is located at Island Beach State Park on the coastal barrier in Ocean County, New Jersey (Fig. 1). The Island Beach core was drilled as part of the New Jersey Coastal Plain Drilling Project (Leg 150X), which constitutes the onshore part of the Ocean Drilling Program's (ODP) New Jersey Sea-level Transect (Legs 150 and 174A; Miller et al., 1994). The principal goal of the transect is to document the effects of Oligocene and Miocene glacioeustatic changes on passive continental margin sedimentation. However, Quaternary sediments, Eocene and Paleocene sediments, and a thin partial section of Upper Cretaceous sediments also were encountered in the Island Beach core. Marine ostracode assemblages recovered from the Cretaceous section are described in this report. Biostratigraphic and paleoenvironmental inferences derived from the ostracode assemblages also are discussed briefly.

The Island Beach drillhole was continuously cored to a depth of $1228 \mathrm{ft}(374.3 \mathrm{~m})$ below a ground elevation of $+12 \mathrm{ft}(3.6 \mathrm{~m})$. A U.S. Geological Survey drilling team using a truck-mounted, hydraulicrotary rig completed the hole during March-May, 1993. A wireline recovery system with a Christensen NQ coring system (nominal core diameter $=1.875 \mathrm{in}$. $[4.76 \mathrm{~cm}]$ ) was used to sample the section below $453 \mathrm{ft}(138.1 \mathrm{~m})$, including the Cretaceous section (Miller et al., 1994).

Thirty-five feet $(10.7 \mathrm{~m})$ of Upper Cretaceous sediments were recovered beneath the Cenozoic section (Fig. 2). Miller et al. (1994) assign this Cretaceous interval (1223-1188 ft [372.8-362.1 m]) to an undifferentiated section of the Navesink Formation and Red Bank Sand. Regionally, the clayey glauconite sands of the Navesink Formation and the overlying micaceous clayey silts of the Sandy Hook Member of the Red Bank Sand constitute a widespread Maastrichtian marine section in northern New Jersey (Owens et al., 1977; Sugarman et al., 1995). The Navesink Formation is also widespread in southern New Jersey where younger Maastrichtian units are absent.

The Navesink-Red Bank section in the Island Beach core (Fig. 2) consists of calcareous, clayey glauconite sand and calcareous glauconitic (sandy) clay (Miller et al., 1994). Samples collected for this study are uniformly bioturbated, as indicated by general texture mottling, irregular clay-poor zones (burrow fills), and small, irregular clay blebs that are free of glauconite sand (truncated burrow linings). Moderately common microfossils and sparse, sand-sized macrofossil fragments are found throughout the section. The grain size and abundance of the glauconite sand decrease upsection; the glauconite is dominantly medium sand at $1221 \mathrm{ft}(372.2 \mathrm{~m})$ and dominantly very fine to fine sand at $1190 \mathrm{ft}(362.7 \mathrm{~m})$. The moist samples show a range of dark and moderate, greenish gray and olive-gray colors. The highest studied sample (1190.2-1189.9 ft [362.8-362.7 m]) consists of glauconitic (about 10\%-20\%), calcareous, sparingly micaceous

${ }^{1}$ Miller, K.G., and Snyder, S.W. (Eds.), 1997. Proc. ODP, Sci. Results, 150X: College Station, TX (Ocean Drilling Program).

${ }^{2}$ U.S. Geological Survey, 926A National Center, Reston, VA 20192, U.S.A. ggohn@usgs.gov

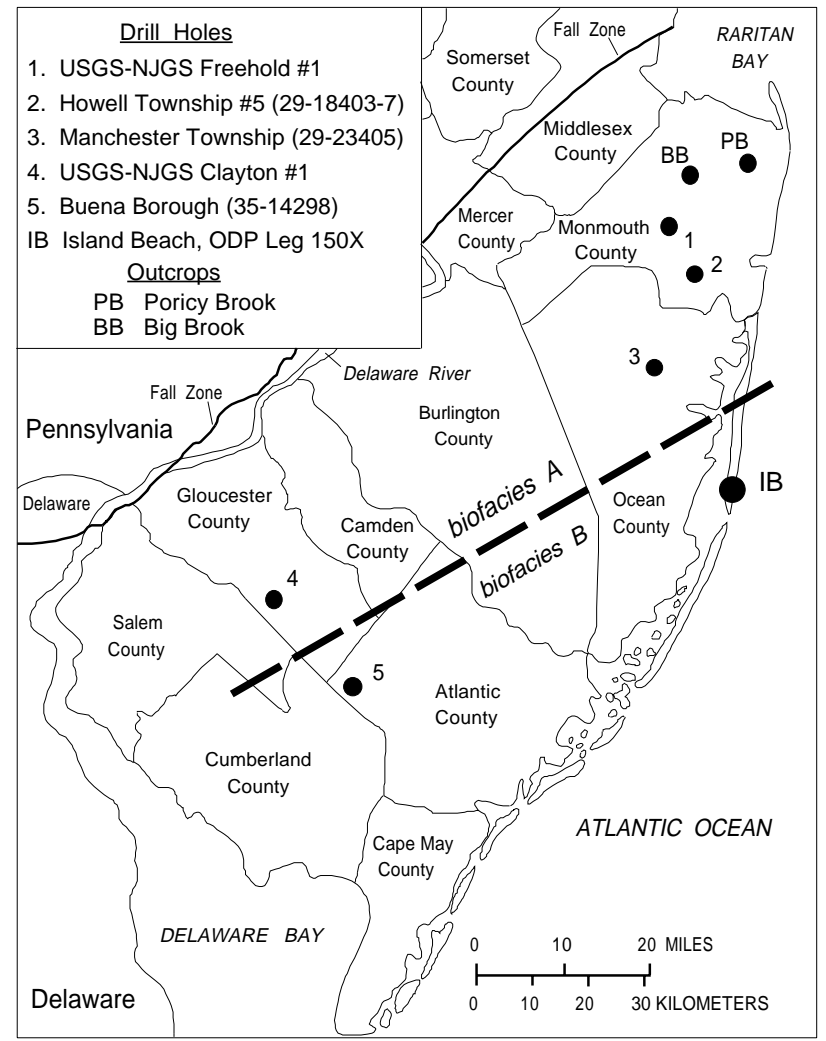

Figure 1. Map showing the location of the Leg 150X Island Beach core site (IB) and additional sample sites in the New Jersey Coastal Plain. Dashed line defines the distribution of two Maastrichtian ostracode biofacies.

silty clay. Discontinuous, very thin clay laminae produce a weak horizontal parting in this sample.

\section{OSTRACODE ASSEMBLAGE}

Five sediment samples representing nearly the full thickness of the recovered Cretaceous section were processed for ostracodes (Fig. 2; Table 1). The samples were dried, partially crushed, soaked in deionized water, and then sieved. Ostracode valves and whole carapaces were picked from the fine-, medium-, and coarse-sand fractions.

All samples were sparingly to moderately productive (Table 1). The number of identifiable taxa in each sample varies from 7 to 17 , and the number of recovered valves per sample varies from 25 to 131 . There is a tendency toward decreased valve abundance (relative to dry sample weight) upward in the section. Twenty identifiable taxa are listed from the assemblage, although only five formally described species are present. 


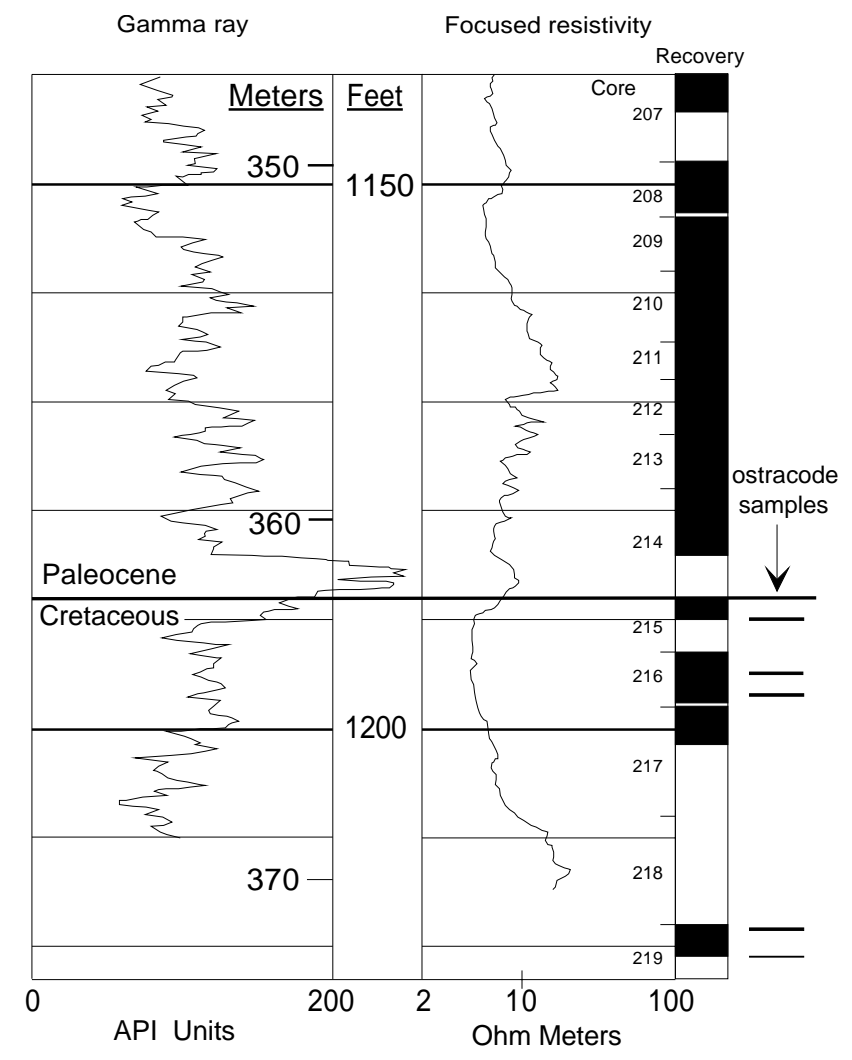

Cretaceous ostracode samples:

Core 150x-Island Beach-

$$
\begin{aligned}
& 215,1,189.9-1,190.2 \mathrm{ft}(362.7-362.8 \mathrm{~m}) \\
& 216,1,194.7-1,195.0(364.1-364.2) \\
& 216,1,196.7-1,197.0(364.7-364.8) \\
& 219,1,218.25-1,218.55(371.3-371.4) \\
& 219,1,221.0-1,221.3(372.1-372.2)
\end{aligned}
$$

Figure 2. Gamma-ray and resistivity logs for the lower part of the Leg 150X Island Beach core. Core recovery (dark) and locations of ostracode samples are indicated.

The five described species, and three additional species of stratigraphic or taxonomic interest, are treated in the Taxonomic Notes (Appendix). Except for Veenia multipora (Skinner, 1956), the previously described species from this assemblage, plus "Cythereis" new species 1, recently were illustrated by Gohn (1995). Taxa designated only as "sp." are represented by small numbers of valves or fragmented valves.

\section{OSTRACODE BIOSTRATIGRAPHY}

Gohn (1995) defined five informal, alpha-numerically designated, ostracode biozones for the Campanian and Maastrichtian marine sections of New Jersey. The youngest zone is Maastrichtian assemblage Zone Ma/a1. The base of this zone is defined by the first appearances of Planileberis? pulchra (Jennings, 1936), and/or "Cythereis" new species 1; the top of the zone is defined by the last

\begin{tabular}{|c|c|c|c|c|c|c|c|}
\hline $\begin{array}{c}\text { Depth } \\
(\mathrm{ft}[\mathrm{m}])\end{array}$ & $\begin{array}{c}1,221 \\
(372.2)\end{array}$ & $\begin{array}{c}1,218 \\
(371.2)\end{array}$ & $\begin{array}{c}1,197 \\
(364.8)\end{array}$ & $\begin{array}{c}1,195 \\
(364.2)\end{array}$ & $\begin{array}{c}1,190 \\
(362.7)\end{array}$ & Totals & $\begin{array}{l}\text { Percent } \\
\text { of total }\end{array}$ \\
\hline Cytherella spp. & 60 & 30 & 27 & 8 & 26 & 151 & $37.8 \%$ \\
\hline Antibythocypris punctilifera & 25 & 30 & 0 & 0 & 0 & 55 & $13.8 \%$ \\
\hline Bairdoppilata spp. & 19 & 4 & 2 & 4 & 4 & 33 & $8.3 \%$ \\
\hline Brachycythere n. sp. 1 & 0 & 7 & 12 & 1 & 13 & 33 & $8.3 \%$ \\
\hline Planileberis? pulchra & 0 & 12 & 9 & 0 & 5 & 26 & $6.5 \%$ \\
\hline Haplocytheridea n. sp. 1 & 0 & 16 & 0 & 0 & 0 & 16 & $4.0 \%$ \\
\hline Veenia multipora & 0 & 6 & 1 & 5 & 2 & 14 & $3.5 \%$ \\
\hline Xestoleberis opina & 4 & 1 & 5 & 0 & 1 & 11 & $2.8 \%$ \\
\hline Cytheropteron $\mathrm{n}$. sp. 1 & 2 & 3 & 5 & 0 & 0 & 10 & $2.5 \%$ \\
\hline Cytherelloidea n. sp. 2 & 0 & 2 & 3 & 2 & 1 & 8 & $2.0 \%$ \\
\hline Curfsina communis & 0 & 3 & 2 & 1 & 1 & 7 & $1.8 \%$ \\
\hline Alatacythere sp. & 2 & 1 & 1 & 0 & 1 & 5 & $1.3 \%$ \\
\hline Brachycythere n. sp. 2 & 2 & 0 & 2 & 0 & 0 & 4 & $1.0 \%$ \\
\hline Cytherelloidea $\mathrm{n} . \mathrm{sp} .1$ & 0 & 1 & 1 & 1 & 1 & 4 & $1.0 \%$ \\
\hline Brachycythere n. sp. 3 & 2 & 0 & 1 & 0 & 0 & 3 & $0.8 \%$ \\
\hline Argilloecia sp. & 0 & 2 & 0 & 0 & 0 & 2 & $0.5 \%$ \\
\hline Krithe? sp. & 0 & 2 & 0 & 0 & 0 & 2 & $0.5 \%$ \\
\hline Cythereis n. sp. 1 & 1 & 0 & 0 & 0 & 0 & 1 & $0.3 \%$ \\
\hline Cytherelloidea sp. & 0 & 1 & 0 & 0 & 0 & 1 & $0.3 \%$ \\
\hline Monoceratina sp. & 0 & 1 & 0 & 0 & 0 & 1 & $0.3 \%$ \\
\hline Unidentified fragments & 0 & 9 & 0 & 3 & 0 & 12 & $3.0 \%$ \\
\hline Totals: & 117 & 131 & 71 & 25 & 55 & 399 & $100.0 \%$ \\
\hline Valves/oz of dry sample & 43.1 & 34.7 & 22.9 & 8.2 & 19.0 & & \\
\hline Valves/g of dry sample & 1.5 & 1.2 & 0.8 & 0.3 & 0.7 & & \\
\hline Number of taxa & 9 & 17 & 13 & 7 & 10 & & \\
\hline
\end{tabular}
appearance of Cretaceous ostracodes. High species diversity and specimen abundance are typical of assemblages in this zone.
Table 1. Distribution of Cretaceous ostracode taxa in samples from the Island Beach core.

Stratigraphically, this zone invariably occurs in sections assigned to the Sandy Hook Member of the Red Bank Sand and/or the underlying Navesink Formation (Gohn, 1995). Species lists for samples from this zone are provided by Jennings (1936; Navesink Formation samples), Adams (1960; Red Bank Sand samples), and Gohn (1992a, 1992b; middle to late Maastrichtian samples), in addition to Gohn (1995).

Gohn (1995) divided assemblage Zone Ma/a1 into two informal subzones on the basis of the presence (older Subzone Ma/a1/a) or absence (younger Subzone Ma/a1/b) of Planileberis? pulchra (Jennings, 1936); the distributions of several undescribed species also aid in characterizing the subzones. Subzone $\mathrm{Ma} / \mathrm{a} 1 / \mathrm{a}$ is typically present in the Navesink Formation and the broadly gradational contact interval between the Navesink and the overlying Sandy Hook Member of the Red Bank Sand. Subzone Ma/a1/b is typically present in the Sandy Hook Member.

In northern New Jersey, assemblage Zone $\mathrm{Ma} / \mathrm{a} 1$ is present at the well known Big Brook (BB) and Poricy Brook (PB) localities in Monmouth County (Fig. 1; Owens et al., 1977; Olsson, 1987). C.C. Smith (in Owens et al., 1977, figs. 91, 92) provided lists of planktonic foraminifers for samples of the Navesink Formation (BB, PB) and the Sandy Hook Member of the Red Bank Sand (PB) at those localities. Calcareous nannofossils (S. Moshkovitz, in Sugarman et al., 1995, fig. 14; P.J. Sugarman, pers. comm., 1992) and ostracodes (Gohn, 1995; this report) subsequently were studied from splits of Smith's original samples. Hence, these exposures provide an excellent opportunity to compare directly the stratigraphic position of assemblage Zone Ma/a1 to important planktonic fossil datums.

The first appearance datum (FAD) of Planileberis? pulchra (Jennings, 1936) and of Gansserina gansseri (Bolli, 1951) are in the same sample near the base of the Navesink Formation at Big Brook (Table 2). Higher in the Navesink, Rosita contusa (Cushman, 1926) and Lithraphidites quadratus Bramlette and Martini (1964) first appear in the same sample at Big Brook; both species also are present in the lowest sample at Poricy Brook. Higher in the section at Poricy Brook, the FAD of Racemiguembelina fructicosa (Egger, 1889) is succeeded by the FAD of Nephrolithus frequens Gorka (1957) in the highest sample containing P.? pulchra. A similar sequence of calcareous nannofossil and ostracode datums is present in the Freehold core in southern Monmouth County and in the Clayton core in Gloucester 
Table 2. Relative positions of selected ostracode, foraminifer, and calcareous nannofossil datums in samples from the Big Brook and Poricy Brook exposures, Monmouth County, N.J.

\begin{tabular}{|c|c|c|}
\hline $\begin{array}{l}\text { Big Brook } \\
\text { samples }\end{array}$ & Microfossil datums & $\begin{array}{l}\text { Poricy Brook } \\
\text { samples }\end{array}$ \\
\hline & $\begin{array}{c}\text { Barren } \\
\text { LAD Cretaceous microfossils } \\
\text { FAD N. frequens, LAD P.? pulchra } \\
\text { FAD } \text { R. fructicosa }\end{array}$ & $\begin{array}{l}21.4 \mathrm{ft}(6.5 \mathrm{~m}) \\
17.2 \mathrm{ft}(5.2 \mathrm{~m}) \\
14.9 \mathrm{ft}(4.5 \mathrm{~m}) \\
11.5 \mathrm{ft}(3.5 \mathrm{~m}) \\
8.9 \mathrm{ft}(2.7 \mathrm{~m}) \\
6.4 \mathrm{ft}(1.9 \mathrm{~m})\end{array}$ \\
\hline $\begin{array}{l}23.2 \mathrm{ft}(7.1 \mathrm{~m}) \\
20.9 \mathrm{ft}(6.4 \mathrm{~m})\end{array}$ & $\begin{array}{c}\text { Barren } \\
\text { FAD L. quadratus \& R. contusa }\end{array}$ & $2.0 \mathrm{ft}(0.6 \mathrm{~m})$ \\
\hline $\begin{array}{l}17.5 \mathrm{ft}(5.3 \mathrm{~m}) \\
15.5 \mathrm{ft}(4.7 \mathrm{~m}) \\
13.7 \mathrm{ft}(4.2 \mathrm{~m}) \\
11.75 \mathrm{ft}(3.6 \mathrm{~m}) \\
9.8 \mathrm{ft}(3.0 \mathrm{~m}) \\
6.7 \mathrm{ft}(2.0 \mathrm{~m})\end{array}$ & $\begin{array}{c}\text { FAD G. gansseri \& P.? pulchra } \\
\text { Barren } \\
\text { Barren } \\
\text { Barren, base Navesink Formation }\end{array}$ & Base \\
\hline $\begin{array}{l}5.2 \mathrm{ft}(1.6 \mathrm{~m}) \\
0.7 \mathrm{ft}(0.2 \mathrm{~m})\end{array}$ & $\begin{array}{l}\text { Barren } \\
\text { Barren }\end{array}$ & \\
\hline Base & & \\
\hline
\end{tabular}

Notes: The labeled samples represent the foraminifer samples studied by C.C. Smith (in Owens et al., 1977, figs. 91, 92). At each site, values (ft [m]) assigned to the samples represent their positions above the base of the exposure. Correlation of a Pycnodonte vesicularis shell bed (20.9 $\mathrm{ft}[6.4 \mathrm{~m}]$ sample) at Big Brook with a similar bed $(2.0 \mathrm{ft}[0.6 \mathrm{~m}]$ sample) at Poricy Brook is suggested by Owens et al. (1977). Smith (in Owens et al., 1977) reported the lowest Racemiguembelina fructicosa (Egger, 1889) specimens from the $11.5 \mathrm{ft}(3.5 \mathrm{~m})$ sample at Poricy Brook; one additional specimen was recovered from the $8.9 \mathrm{ft}(2.7 \mathrm{~m})$ sample during the ostracode study.

County (Gohn, 1992a, 1992b; Sugarman et al., 1995, figs. 12, 15; Self-Trail and Bybell, 1995). In the Clayton core (Fig. 1), the FAD of $N$. frequens precedes the last appearance datum (LAD) of P.? pulchra (Jennings, 1936). It is apparent from these sections that ostracode assemblage Zone $\mathrm{Ma} / \mathrm{a} 1$ is biochronostratigraphically equivalent to Maastrichtian calcareous nannofossil Zones CC25b-c and CC26 (Perch-Nielsen, 1985), to the Maastrichtian foraminiferal Gansserina gansseri Zone (Caron, 1985), and probably to the chronozone of the Maastrichtian foraminiferal Abathomphalus mayaroensis Zone (Caron, 1985).

In the Leg 150X Island Beach core, "Cythereis" new species 1 occurs in the lowest studied sample, and Planileberis? pulchra (Jennings, 1936) is present in three of the four higher samples, including the highest sample at $1190 \mathrm{ft}(362.7 \mathrm{~m}$; Table 1$)$. Therefore, the entire studied Cretaceous section at Island Beach, and very likely the entire Cretaceous section, can be assigned to Maastrichtian ostracode assemblage Subzone Ma/a1/a. The occurrences of Curfsina communis (Israelsky, 1929), Antibythocypris punctilifera (Jennings, 1936), and Xestoleberis opina (Schmidt, 1948) in this section are compatible with this zonal assignment. Assignment of the Island Beach Cretaceous section to ostracode Subzone Ma/a1/a is consistent with its assignment to Maastrichtian calcareous nannofossil Zones CC25 and CC26 by Miller et al. (1994, p. 25).

\section{PALEOENVIRONMENTS}

In New Jersey, two ostracode biofacies are recognized within ostracode assemblage Subzone Ma/a1/a: Biofacies A, which is found in the outcrop belt and updip drill holes, and Biofacies B, which is found in comparatively downdip drill holes (Fig. 1).

Ostracode assemblages representing Biofacies A (Jennings, 1936; Gohn, 1992a, 1992b) contain numerous species, especially Cytherideinae species, which dominate inner-neritic upper Campanian and Maastrichtian siliciclastic sections throughout the Atlantic Coastal
Plain (Brouwers and Hazel, 1978). These inner-neritic species include Haplocytheridea everetti (Berry, 1925), Haplocytheridea renfroensis Crane, 1965, Amphicytherura curta (Jennings, 1936), Brachycythere ovata (Berry, 1925), Curfsina communis (Israelsky, 1929), Escharacytheridea pinochii (Jennings, 1936), Fissocarinocythere huntensis (Alexander, 1929), Veenia arachoides (Berry, 1925), and several species of Antibythocypris Jennings, 1936.

Most of these inner-neritic species are absent downdip in the Leg 150X Island Beach core and in a core located at Buena, Atlantic County (Fig. 1). Instead, downdip Biofacies B is dominated by platycopid taxa (Cytherella spp., Cytherelloidea spp.) and other smoothvalved forms (Bairdoppilata sp., Argilloecia sp., Krithe sp.). These taxa constitute half of the valves collected from the Island Beach core samples (Table 1). Several other distinctive species that are rare or absent elsewhere in the Atlantic Coastal Plain, particularly Veenia multipora (Skinner, 1956) and Brachycythere new species 1, are characteristic of Biofacies B.

Both biofacies represent shelf paleoenvironments with low rates of terrigenous sedimentation, as inferred from the strongly glauconitic and bioturbated character of their associated sediments. However, Biofacies B is considered to represent a deeper water, shelf paleoenvironment than does Biofacies A for several reasons:

1. the relative abundance of smooth-valved species in Biofacies $\mathrm{B}$, which is a characteristic of chalky, deeper water facies in Campanian-Maastrichtian sections of the Atlantic and Gulf of Mexico Coastal Plains (Hazel and Brouwers, 1982, p. 177);

2. a paucity of the common inner-neritic species of Haplocytheridea Stephenson, 1936, Antibythocypris Jennings, 1936, and Escharacytheridea Brouwers and Hazel, 1978, in Biofacies B; and

3. the geographic distributions of the two biofacies in the New Jersey Coastal Plain where Biofacies B is located in the more downdip position (Fig. 1).

\section{SUMMARY}

A distinctive assemblage of Late Cretaceous ostracodes is present in the lower $35 \mathrm{ft}(10.7 \mathrm{~m})$ of the Coastal Plain section recovered in the Leg 150X Island Beach core. The assemblage is assigned to informal ostracode assemblage Subzone Ma/a1/a of Gohn (1995). Elsewhere in New Jersey, sections assigned to this subzone contain planktonic foraminifers and calcareous nannofossils indicative of a middle to late Maastrichtian age. The Island Beach ostracode assemblage contains abundant specimens of smooth-valved taxa, principally platycopids, and lacks most of the common inner-neritic Cytherideinae species that characterize updip Maastrichtian ostracode assemblages in New Jersey. The Island Beach assemblage is interpreted to represent a relatively deep-water shelf paleoenvironment.

\section{REFERENCES}

Adams, J.K., 1960. Note on lower Tertiary and Upper Cretaceous Ostracoda from New Jersey. J. Paleontol., 34:371-372.

Brouwers, E.M., and Hazel, J.E., 1978. Ostracoda and correlation of the Severn Formation (Navarroan: Maestrichtian) of Maryland. J. Paleontol. Suppl., 52:6.

Caron, M., 1985. Cretaceous planktic foraminifera. In Bolli, H.M., Saunders, J.B., and Perch-Nielsen, K. (Eds.), Plankton Stratigraphy: Cambridge (Cambridge Univ. Press), 17-86.

Crane, M.J., 1965. Upper Cretaceous ostracodes of the Gulf Coast area. Micropaleontology, 11:191-254.

Gohn, G.S., 1992a. Distribution of selected Campanian and Maastrichtian Ostracoda in stratigraphic test holes of the New Jersey Coastal Plain. Open-File Rept.-U.S. Geol. Surv., 92-399. 
1992b. Preliminary ostracode biostratigraphy of subsurface Campanian and Maastrichtian sections of the New Jersey Coastal Plain. In Gohn, G.S. (Ed.), Proceedings of the 1988 U.S. Geological Survey Workshop on the Geology and Geohydrology of the Atlantic Coastal Plain: Geol. Surv. Circ. (U.S.), 1059:15-21.

1995. Ostracode biostratigraphy of the Upper Cretaceous marine sediments in the New Jersey Coastal Plain. In Baker, J.E.B., (Ed.), Contributions to the Paleontology of New Jersey, XII: Wayne, NJ (The Geological Association of New Jersey), 87-101.

Hazel, J.E., and Brouwers, E.M., 1982. Biostratigraphic and chronostratigraphic distribution of ostracodes in the Coniacian-Maastrichtian (Austinian-Navarroan) in the Atlantic and Gulf Coastal Province. In Maddocks, R.F. (Ed.), Texas Ostracoda, Guidebook of Excursions and Related Papers for the Eighth International Symposium on Ostracoda: Houston, TX (Univ. of Houston), 166-198.

Israelsky, M.C., 1929. Upper Cretaceous Ostracoda of Arkansas. Arkansas Geol. Surv. Bull., 4.

Jennings, P.H., 1936. A microfauna from the Monmouth and basal Rancocas Groups of New Jersey. Bull. Am. Paleontol., 23:78:1-76.

Jones, T.R., 1849. A Monograph of the Entomostraca of the Cretaceous Formation of England: London (Palaeontographical Society).

Miller, K.G., Sugarman, P., Van Fossen, M., Liu, C., Browning, J.V., Queen, D., Aubry, M.-P., Burckle, L.D., Goss, M., and Bukry, D., 1994. Island Beach site report. In Miller, K.G., et al., Proc. ODP, Init. Repts., 150X: College Station, TX (Ocean Drilling Program), 5-33.

Nine, O.W., Jr., 1954. A microfauna from the Upper Cretaceous Navesink Formation in New Jersey [Ph.D. dissert.]. Rutgers Univ., New Brunswick, NJ.

Olsson, R.K., 1987. Cretaceous stratigraphy of the Atlantic Coastal Plain, Atlantic Highlands of New Jersey. In Roy, D.C. (Ed.), Northeastern Section of the Geological Society of America Centennial Field Guide, 5:8790.

Owens, J.P., Sohl, N.F., and Minard, J.P., 1977. A field guide to Cretaceous and lower Tertiary beds of the Raritan and Salisbury embayments, New Jersey, Delaware, and Maryland. Am. Assoc. Petrol. Geol. and Soc. Econ. Paleo. and Min. Conf. Washington, DC.

Perch-Nielsen, K., 1985. Mesozoic calcareous nannofossils. In Bolli, H.M., Saunders, J.B., and Perch-Nielsen, K. (Eds.), Plankton Stratigraphy: Cambridge (Cambridge Univ. Press), 329-426.

Schmidt, R.A.M., 1948. Ostracoda from the Upper Cretaceous and lower Eocene of Maryland, Delaware, and Virginia. J. Paleontol., 22:389-431.

Self-Trail, J.M., and Bybell, L.M., 1995. Cretaceous and Paleogene calcareous nannofossil biostratigraphy of New Jersey. In Baker, J.E.B. (Ed.), Contributions to the Paleontology of New Jersey, XII: Wayne, NJ (The Geological Association of New Jersey), 102-139.

Skinner, R.C., 1956. Ostracoda from basal Arkadelphia Marl exposures near Hope, Arkansas. Trans., Gulf Coast Assoc. of Geological Societies, 6:179-204.

Smith, J.K., 1978. Ostracoda of the Prairie Bluff Chalk, Upper Cretaceous, (Maestrichtian) and the Pine Barren Member of the Clayton Formation, lower Paleocene, (Danian) from exposures along Alabama State Highway 263 in Lowndes County, Alabama. Trans., Gulf Coast Assoc. of Geological Societies, 28:539-579.

Sugarman, P.J., Miller, K.G., Bukry, D., Feigenson, M.D., 1995. Uppermost Campanian-Maestrichtian strontium isotopic, biostratigraphic, and sequence stratigraphic framework of the New Jersey Coastal Plain. Geol. Soc. Am. Bull., 107:19-37.

Date of initial receipt: 13 March 1996

Date of acceptance: 19 September 1996

Ms 150XSR-317

\section{APPENDIX}

\section{TAXONOMIC NOTES}

These notes are limited to discussions of previously described species and undescribed species of stratigraphic or taxonomic interest.

$$
\text { Antibythocypris punctilifera (Jennings, 1936) }
$$

Cytheridea punctilifera Jennings, 1936, p. 58, pl. 7, fig. 11.

Antibythocypris punctilifera (Jennings, 1936). Gohn, 1995, p. 91, pl. 2, fig. 12.
Cytheridea sepulchra Jennings, 1936, p. 59, pl. 7, fig. 12.

Haplocytheridea punctura Schmidt, 1948, p. 425, pl. 61, figs. 27-31.

Remarks. The antimerodont hinge of this species suggests placement in Antibythocypris Jennings, 1936, rather than Haplocytheridea Stephenson, 1936. Cytheridea sepulchra Jennings, 1936, is the female dimorph of Cytheridea punctilifera Jennings, 1936, as originally noted by Nine (1954). Antibythocypris punctilifera (Jennings, 1936) also is illustrated from New Jersey sections in an unpublished dissertation by Nine (1954). Cytheridea punctilifera Jennings, 1936, of Skinner (1956) and Antibythocypris hooksi Smith, 1978, both from Maastrichtian sections of the Gulf of Mexico Coastal Plain, may represent this species, but specimens of the Gulf Coast forms were not examined for this study.

Occurrences. Present in upper Campanian and Maastrichtian marine sections of New Jersey and Delaware.

\section{Brachycythere new species 1}

Pl. 1, Fig. 2

Description. Moderate-sized, laterally compressed valves; strongly compressed anterior and posterior marginal areas. Anterior margin more broadly rounded than posterior margin. Lateral surface is smooth, where well preserved, with a straight ventrolateral ridge.

Remarks. The size, shape, and minimal ornamentation distinguish this species from all described Campanian and Maastrichtian species of Brachycythere Alexander, 1933, in the Atlantic Coastal Plain.

Occurrences. Known only from Maastrichtian sections in the Leg 150X Island Beach core and the Buena core.

\section{Curfsina communis (Israelsky, 1929)}

Pl. 1, Fig. 3

Cythereis communis Israelsky, 1929, p. 14, pl. 3a, fig. 9-13.

Cythereis communis (Israelsky, 1929). Jennings, 1936, p. 52, pl. 7, fig. 3.

Curfsina communis (Israelsky, 1929). Gohn, 1995, p. 91, pl. 1, fig. 5.

Remarks. Specimens of this long-ranging species from the Island Beach core have a faint polygonal pattern on the lateral surface defined by straight, very low ridges. The synonymy for this common species is restricted to the original designation and illustrated specimens from New Jersey. Curfsina communis (Israelsky, 1929) also is illustrated from New Jersey sections in the unpublished dissertation by Nine (1954).

Occurrences. Common in middle Campanian through Maastrichtian marine sections of the Atlantic and Gulf of Mexico Coastal Plains.

$$
\text { "Cythereis" new species } 1
$$

“Cythereis" new species 1, Gohn, 1995, p. 91, pl. 1, fig. 3.

Remarks. Nine (1954) also recognized this species.

Occurrences. This species is known only from the Navesink-Red Bank marine sections of New Jersey.

\section{Cytherelloidea new species 1}

Cytherelloidea williamsoniana Jones, 1849 of Jennings, 1936, p. 43, pl. 6, fig. 5.

Remarks. Nine (1954) compared the New Jersey species to specimens of Cytherelloidea williamsoniana Jones, 1849, from the Gault of England and concluded that the New Jersey form is a separate species. I examined Jones' (1849) original illustrations of C. williamsoniana Jones, 1849, and also conclude that the New Jersey and British forms are not conspecific.

Occurrences. This species is reported only from the upper Campanian and Maastrichtian sections of New Jersey.

\section{Planileberis? pulchra (Jennings, 1936)}

$$
\text { Pl. 1, Fig. } 1
$$

Cythereis pulchra Jennings, 1936, p. 54, pl. 7, fig. 6.

Planileberis? pulchra (Jennings, 1936). Gohn, 1995, p. 91, pl. 1, fig. 1.

Cythereis cf. Cythereis costatana Israelsky, 1929 of Smith, 1978, p. 554, pl. 6 , figs. 1-2.

Description. Carapace is strongly compressed laterally. Lateral surfaces are coarsely pitted to coarsely reticulate with a prominant smooth muscle 
node and prominant horizontal dorsal and ventral ridges. The dorsal ridge turns downward at its posterior termination and ends in a smooth node that tends to have two downward extensions.

Remarks. Planileberis? pulchra (Jennings, 1936) also is illustrated from Maastrichtian sections of New Jersey in the unpublished dissertation by Nine (1954). Cythereis costatana reticulata Crane, 1965, is a similar species from the Corsicana Marl of Texas.

Occurrences. Present in Maastrichtian sections of New Jersey, South Carolina, and Alabama (Smith, 1978). This species generally is restricted to glauconitic or chalky shelf facies.

\section{Veenia multipora (Skinner, 1956)}

$$
\text { Pl. 1, Fig. } 4
$$

Cythere multipora Skinner, 1956, p. 190, pl. 2, figs. 4a-d.

Veenia multipora (Skinner, 1956). Crane, 1965, p. 227, pl. 7, fig. 11.

Veenia adkinsi Smith, 1978, p. 554, pl. 6, figs. 3-5.
Description. Large carapace is coarsely reticulate in swollen mid-valve area. Distinct dorsal, medial, and ventrolateral ridges. Compressed anterior and posterior marginal areas are smooth to irregular, lacking coarse, deep pits and reticulations.

Occurrences. Present in Maastrichtian sections of New Jersey and South Carolina, and in upper Campanian and Maastrichtian sections in the Gulf of Mexico Coastal Plain.

Xestoleberis opina Schmidt, 1948

Xestoleberis opina Schmidt, 1948, p. 410, pl. 61, fig. 15, 16.

Xestoleberis opina (Schmidt, 1948). Gohn, 1995, p. 91, pl. 3, fig. 9.

Remarks. The synonymy for this common species is restricted to the original designation and illustrated specimens from New Jersey. Xestoleberis opina Schmidt, 1948, also is illustrated from New Jersey sections in the unpublished dissertation by Nine (1954).

Occurrences. Common in upper Campanian and Maastrichtian sections of the Atlantic and Gulf of Mexico Coastal Plains. 


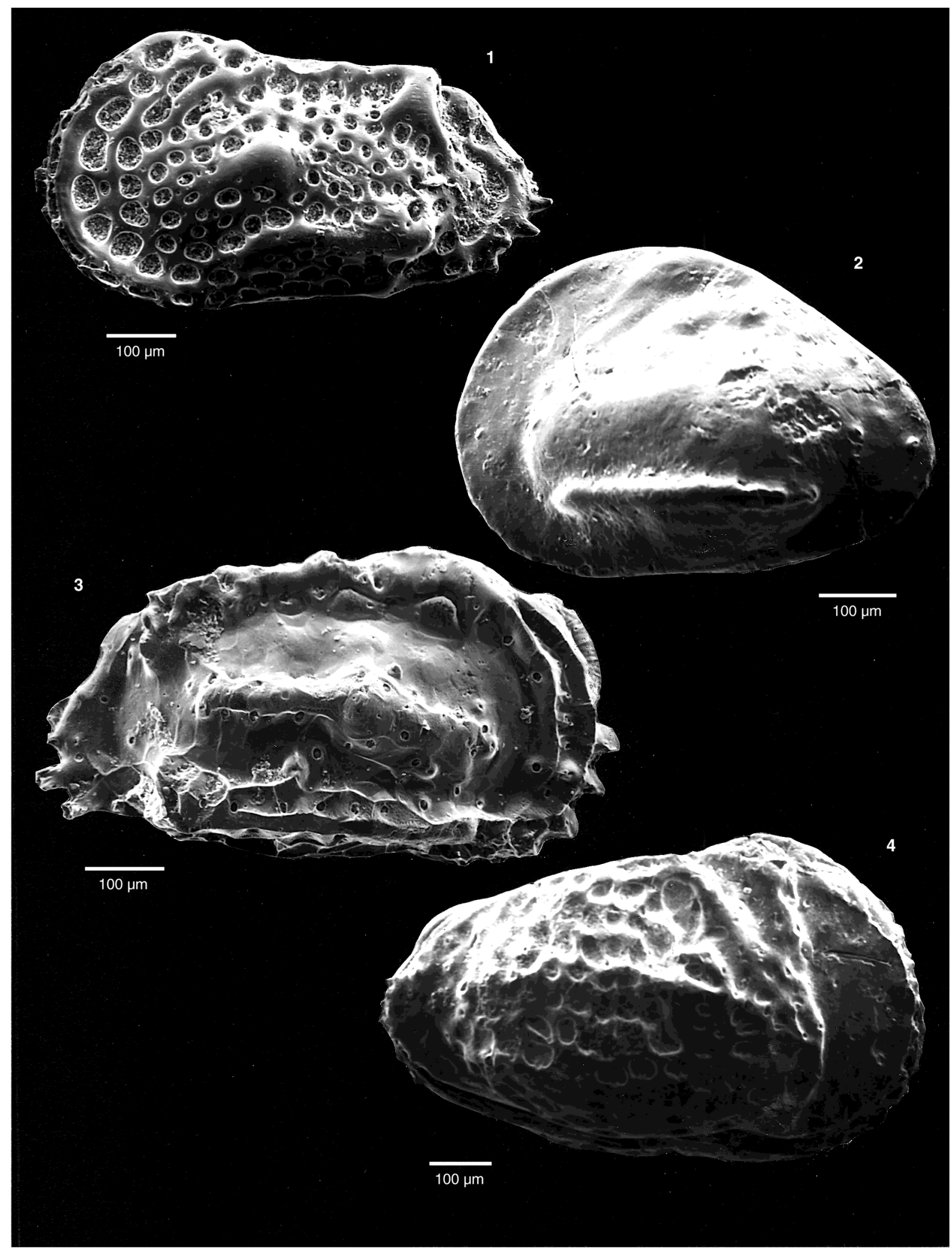

Plate 1. Cretaceous Ostracoda from Leg 150X-Island Beach core. Scale bars $=100$ microns. 1. Planileberis? pulchra (Jennings, 1936), Sample 219, 1218.55$1218.25 \mathrm{ft}$ (371.4-371.3 m), lateral view of female left valve. 2. Brachycythere new species 1, Sample 216, 1197.0-1196.7 ft (364.8-364.7 m), lateral view of female left valve. 3. Curfsina communis (Israelsky, 1929), Sample 219, 1218.55-1218.25 ft (371.4-371.3 m), lateral view of right valve. 4. Veenia multipora (Skinner, 1956), Sample 219, 1218.55-1218.25 ft (371.4-371.3 m), lateral view of right side of female carapace. 